\title{
Ege Üniversitesi Hastanesinde görülen deri melanomlarının epidemiyolojik ve genel sağ kalım özellikleri
}

\section{Epidemiological and overall survival properties of cutaneous melanomas at Ege University Hospital}

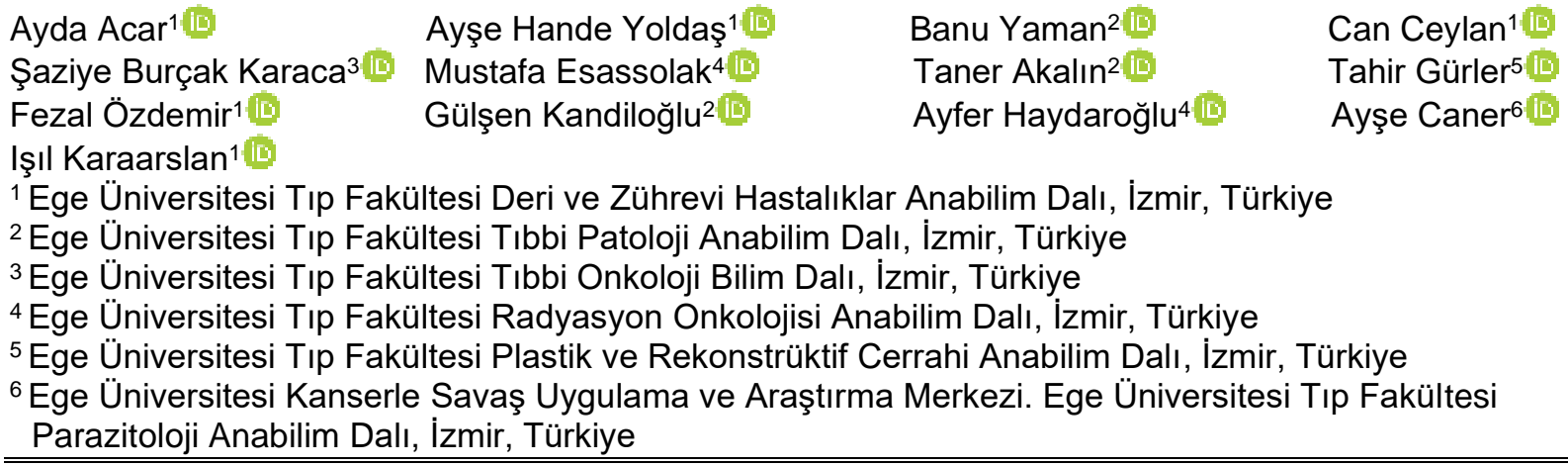

Öz

Amaç: Bu çalışmada Ege Üniversitesi Hastanesi veri tabanındaki 1992-2017 yılları arası melanom tanısı alan hastaların epidemiyolojik ve genel sağ kalım özelliklerinin değerlendirilmesi amaçlanmıştır.

Gereç ve Yöntem: Ege Üniversitesi Kanserle Savaş Araştırma ve Uygulama Merkezinin özel eğitimli ve sertifikalı kanser kayıt elemanları tarafından CANREG-4 programı ile kaydedilen 1992-2017 yılları arasında Ege Üniversitesinde kayıtlı 1530 melanom tanılı hastanın verileri toplanmıştır. Kategorik değişkenler arası ilişki varlığı Ki-Kare yöntemiyle değerlendirilirken, gruplar arası nümerik değişkenler Tek Yönlü Varyans Analizi ve Tukey HSD Testi ile karşılaştııılı. Sağ kalım üzerine kategorik değişkenlerin etkileri Kaplan Meier ve LogRank (Mantel-Cox) yöntemleri ile incelenirken, nümerik değişkenler için CoxRegresyon analizi kullanıldı. Tüm Hipotez testleri 0,05 önem seviyesinde uygulandı.

Bulgular: Bin beş yüz otuz melanom olgusunun $\% 53,1^{\prime} i$ erkek, $\% 46,9^{\prime} u$ kadındı. Yaş ortalaması $54,14 \pm 16,537$ 'ydi. Yüzeyel yayılan melanom ve lentigo malign melanom en sık görülen alt tiplerdi. Hastaların takip süresi 0 ile 313 ay arasında değişmekteydi. Ortalama genel sağ kalım (GSK) süresi $147,4 \pm 5,3$ aydı. Yaş artışı ile GSK süresi azalmaktaydı $(p<0,01)$. Kadınlarda erkeklere göre GSK süresi daha yüksekti $(p<0,001)$.

Sonuçlar: Çalışmamızda tanı sırasında ileri yaş, erkek cinsiyet, tümörün in situ olmaması, lenf bezi tutulumu ve metastaz varlığı sağ kalımı azaltan faktörlerdir. Beş yıllık GSK nodüler melanomda diğer histopatolojik alt tiplere göre daha kısadır. Beş yıllık GSK; lokalize hastalıkta \%90, lokal yayılım durumunda $\% 52$, bölgesel yayılımda $\% 56$, ilerlemiş metastatik hastalıkta ise $\% 15$ 'tir. Kutanöz melanomda erken tanı prognozu önemli ölçüde etkilemektedir. Melanomun yüksek mortalite oranı dikkate alındığında; daha erken dönemde başvuruyu sağlamak açısından; toplumsal bilinç düzeyinin olabildiğince arttırılması son derece önemlidir.

Anahtar Sözcükler: Malign melanom, kutanöz melanom, sağ kalım.

\begin{abstract}
Aim: We aimed to evaluate the epidemiological and survival characteristics of patients diagnosed as melanoma in the database of Ege University Hospital between 1992-2017.
\end{abstract}

Sorumlu yazar: Ayda Acar

Ege Üniversitesi Tıp Fakültesi Deri ve Zührevi Hastalıklar

Anabilim Dalı

E-posta: aydaerbas@yahoo.com 
Materials and Methods: The data of 1530 patients diagnosed with melanoma enrolled at Ege University between 1992-2017, recorded by the CANREG 4 program by specially trained and certified cancer registry staff of the Ege University Cancer Control Research and Application Center, were collected. While the existence of the relationship between categorical variables was evaluated with the Chi-Square method, the numerical variables between the groups were compared with the One Way Variance Analysis and the Turkey HSD Test. While the effects of categorical variables on survival were examined by Kaplan Meier and Log Rank (Mantel-Cox) methods, Cox-Regression analysis was used for numerical variables. All Hypothesis tests were appliedat 0.05 significance level.

Results: Of the 1530 melanoma cases, 53.1\% were male and $46.9 \%$ were female. The average age was $54.14 \pm 16.537$. Superficial spreading melanoma and lentigo malignant melanoma were the most common subtypes. $11.6 \%$ of the melanoma lesions were in situ, $43.6 \%$ were localized, $6.7 \%$ were locally spread, $16.9 \%$ were regionally spread, $21.1 \%$ were advanced. The follow-up period of the patients ranged from 0 to 313 months. The mean survival time was $147.4 \pm 5.3$ months. The survival rate decreased with increasing age $(p<0.01)$. The duration of survival was higher in women than in men $(p<0,001)$.

Conclusions: In our study, older age at diagnosis, male gender, not having in situ tumor, lymph node involvement and presence of metastasis are factors that decrease survival. Five-year survival is shorter in nodular melanoma than other histopathological subtypes. Five-year survivals were; 90\% in localized disease, $52 \%$ in local spread, 56\% in regional spread, $15 \%$ in advanced metastatic disease. Early diagnosis affects prognosis in cutaneous melanoma. For this reason, it is important to raise awareness of the society and ensure that patients apply earlier.

Keywords: malignant melanoma, cutaneous melanoma, survival.

\section{Giriş}

Melanom melanositlerden köken alan bir kanserdir. En sık deride yerleşmekle birlikte gözde konjuntiva ve üvea, mukozalar ve leptomeninkslerde de gelişebilir (1). Kutanöz melanomlar tüm melanomların \%91,2'sini oluşturmaktadır (2). Melanom dışı deri kanserlerine göre daha az sıklıkta görülmesine rağmen deri kanserine bağlı ölümlerin önde gelen nedenidir.

Melanom gelişiminde genetik ve çevresel faktörler birlikte rol oynamaktadırlar. En önemli çevresel faktör ultraviyole (UV) maruziyetidir. Kutanöz melanomlar için tanımlanmış risk faktörleri; açık ten rengi, kızıl saç, kseroderma pigmentozum gibi DNA tamir defektlerine, 100'den fazla melanositik nevüse, 5 'den fazla atipik nevüse, dev konjenital nevüse ve çok sayıda solar lentigoya sahip olmak, kişinin ailesinde veya kendisinde melanom öyküsü olması, aralıklı ve şiddetli ya da kronik olarak güneş maruziyeti, güneş yanığı öyküsü, 200 seanstan fazla psoralen + Ultraviyole A (PUVA) tedavisi almak, immünsuprese durumda olmak ve solaryum maruziyetidir $(1,3,4)$.

Kutanöz melanomun tanımlanmış dört ana alt tipi mevcuttur. En sık görülen tip yüzeyel yayılan melanom (YYM) genellikle renk varyasyonlarının görüldüğü kahve-siyah makül şeklinde başlayıp plak haline gelir, üzerinde papül veya nodül gelişimi olabilir. İkinci sıklıkta görülen nodüler melanom (NM) genellikle üzeri ülsere ve kanamalı olabilen mavi-siyah nodül şeklinde kendini gösterir. Özellikle kümülatif güneş maruziyeti ile ilişkili olan lentigo malign melanom (LMM) daha çok yaşlı bireylerin yüzlerinde asimetrik kahverengi-siyah makül olarak izlenmektedir. En az görülen tip olan akral lentijinöz malign melanom (ALMM) palmoplantar bölge ve tırnak yerleşimi gösterir. Amelanotik melanom, spitzoid melanom, dezmoplastik melanom, malign mavi nevüs gibi daha az görülen melanom varyantları da mevcuttur $(1,4)$.

Melanomun primer tedavisi cerrahidir. Öncelikle 1-3 mm sınırla eksizyonel biyopsi yapılması önerilmektedir. Histopatolojik olarak melanom tanısı doğrulandıktan sonra in situ melanomlarda $0,5 \mathrm{~cm}, 2 \mathrm{~mm}$ 'nin altındaki tümör kalınlıklarında 1 $\mathrm{cm}, 2 \mathrm{~mm}$ 'nin üzerindeki tümör kalınlıklarında 2 $\mathrm{cm}$ cerrahi sınırla tekrar eksizyon yapılması önerilmektedir (5). Breslow kalınlığının 1 mm'den büyük olması ve 0,8 mm'den büyük ve eşlik eden ülserasyon, yüksek mitotik hız, lenfovasküler invazyon gibi diğer risk faktörlerinin olması durumunda sentinel lenf bezi biyopsisi reeksizyon işlemi ile birlikte yapılır (5).

\section{Gereç ve Yöntem}

Bu çalışmada Ege Üniversitesi (EÜ) Hastanesi veri tabanındaki 1992-2017 yılları arası melanom tanısı alan hastaların epidemiyolojik ve genel sağ kalım (GSK) özellikleri değerlendirilmiştir.

EÜ Kanserle Savaş Araştırma ve Uygulama Merkezinin (EÜKAM) özel eğitimli ve sertifikalı kanser kayıt elemanları tarafından kaydedilen 1992-2017 yılları arasında, Ege Üniversitesinde 
kayıtlı 1530 melanom tanılı hastanın; tanı yaşı, cinsiyeti, tümör yerleşimi, histopatolojik alt tipi, hastalık evresi, uygulanan tedavi yöntemleri, son durumları, takip süreleri değerlendirildi. Genel sağ kalımlar sağ kalım bilgilerine ulaşılan olgularda, evreleme çalışması yapılanlar olgularda evrelemeler değerlendirildi. Çalışma için EÜ Tıbbi Araştırmalar Etik Kurulundan 202.1T/20 numarası ile onay alındı. CANREG 4 programı ile kaydedilen, SPSS 18.0 versiyonuna aktarılan retrospektif veriler ile hasta ve hastalık özelliklerinin sıklığı ve bu özelliklerin tümör yerleşim sıklığı açısından karşılaştırmaları, GSK araştırıldı. İstatistiksel analizler IBM Corp. Released 2017. IBM SPSS Statistics for Windows, Version 25.0. Armonk, NY: IBM Corp. Paket programında gerçekleştirildi. Kategorik değişkenler arası ilişki varlığı Ki-Kare yöntemiyle değerlendirilirken, gruplar arası nümerik değişkenler Tek Yönlü Varyans Analizi ve Tukey HSD Testi ile karşılaştırıldı. Genel sağ kalım üzerine kategorik değişkenlerin etkileri Kaplan Meier ve LogRank (Mantel-Cox) yöntemleri ile incelenirken, nümerik değişkenler için CoxRegresyon analizi kullanıldı. Tüm Hipotez testleri 0,05 önem seviyesinde uygulandı.

\section{Bulgular}

Ege Üniversitesi Kanser Araştırma Merkezinde 1992 ile 2017 yılları arasında kayıtlı 1530 melanom olgusunun yıllar içindeki sayısal ve mortalite dağılımları (Şekil-1)'de gösterilmiştir. Yıllar içinde görülen vaka sayısındaki artış istatistiksel olarak anlamlı idi ( $F$ : 8488.688 $\mathrm{p}<0.001)$. İki binli yıllara kadar mortalitede artış görülmekteyken, daha sonra mortalitede artış eğilimi anlamlılığını kaybetmektedir (F=1.067 $\mathrm{p}=0.344$ ).

Yaş gruplarına göre sayısal dağılımlar (Tablo1)'de gösterilmiştir. Hastaların \%53,1'i erkek, $\% 46,9$ 'u kadındı. Yaş ortalaması 54,14 $\pm 16,537$ (1-96) idi. Lezyon yerleşim yerleri sıklığına göre şöyle sıralanmaktaydı; alt ekstremite ve kalça (\%23), gövde $(\% 21,9)$, yüz $(\% 16,1)$, üst ekstremite ve omuz $(\% 12,8)$, saçlı deri ve boyun $(\% 6,3)$, dış kulak $(\% 3,2)$, göz kapağı $(\% 2,1)$ ve dudak $(\% 0,7)$. Hastaların \%13,7'sinin lezyon yerleşim yeri tam olarak belirtilmemişti.

Hastaların \%54,2'sinde histopatolojik alt tip belirtilmemişti. Histolojik alt tipin belli olduğu 701 hastada; LMM ve YYM \%25,5 ile aynı sıklıkta görülürken, NM \%23,4, ALMM \%21,4 oranlarında görüldü (Tablo-2).

Sekiz yüz doksan yedi $(\% 58,6)$ olgunun T evresi ile ilgili bilgi mevcuttu. T evresi bilgisi olan olguların dağılımı şu şekildeydi; \%73,8 lokal, $\% 16,2$ ileri ve $\% 10$ in situ. Olguların 794'ünün $(\% 51,9)$ lenf bezi tutulumu ile ilgili bilgi mevcuttu. Tutulum bilgisi mevcut olan hastaların $\% 67,1$ 'inde lenf bezi tutulumu yokken, \%32,9'unda vardı.

Sekiz yüz otuz sekiz $(\% 54,8)$ hastanın metastaz durumu ile ilgili bilgi mevcuttu. Metastaz durumu ile bilgisi olan hastaların $\% 80,1$ 'inde metastaz yokken, \%19,9'unda metastaz vardı.

Evre özeti bilgisi $786(\% 51,3)$ hastada vardı. Evre özet bilgisi olan hastaların \%11,6'sı in situ, $\% 43,6$ 'sı lokalize, \%6,7'si lokal yayılım göstermiş, $\% 16,9$ 'u bölgesel yayılım göstermiş, \%21,1'inde ise ilerlemiş hastalık mevcuttu (Şekil-2).

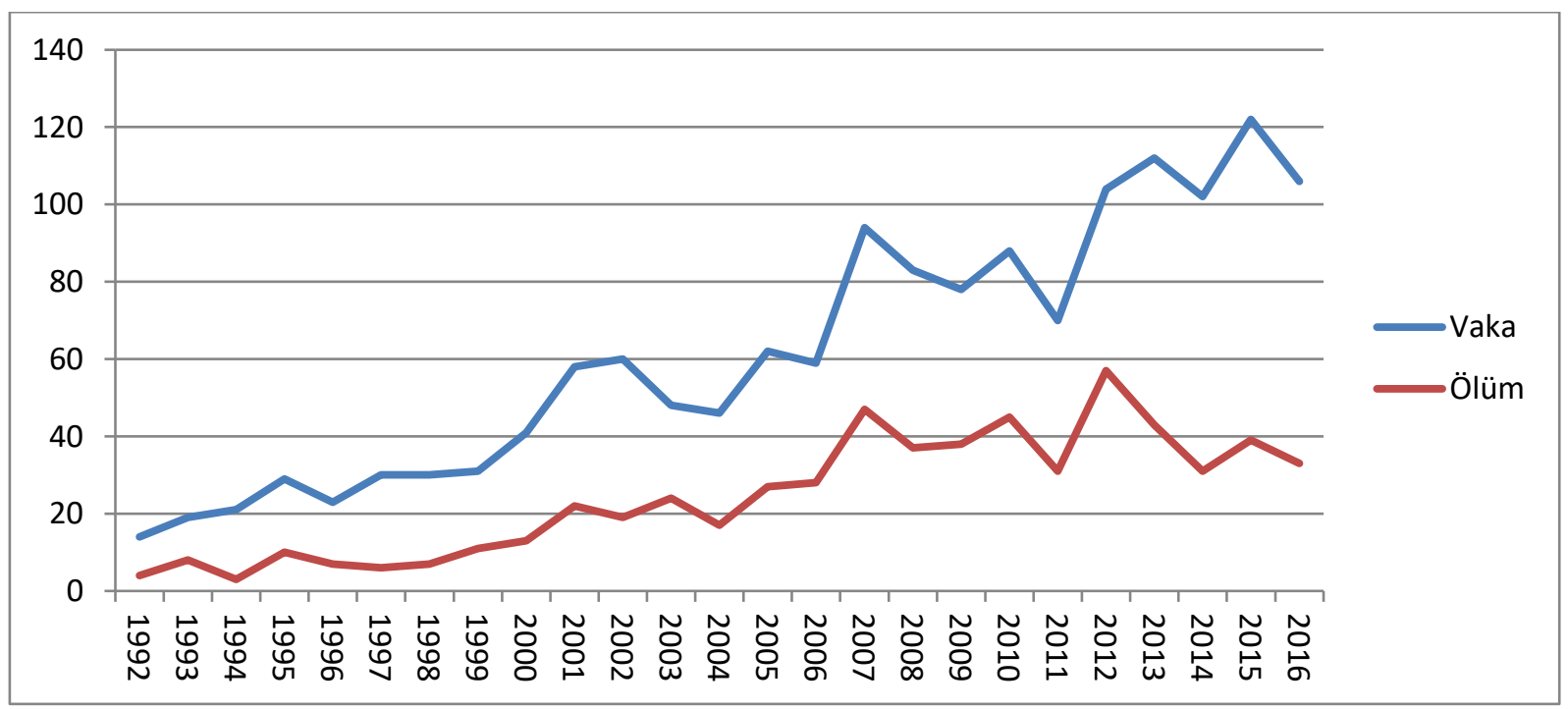

Şekil-1. Ege Üniversitesi Tıp Fakültesi-hastanesi melanom olgularında görülme ve mortalitede artış eğilimi. Olgu sayısındaki artış istatistiksel olarak anlamlı idi (F: 8488.688 p<0.001). İki binli yıllara kadar mortalitede artış vardır, daha sonra mortalitede artış eğilimi anlamlıı̆ını kaybetmektedir ( $F=1.067$ p=0.344). 


\section{Evre Özeti}

घin Situ $\quad$ Lokalize $\square$ Lokal Yayılım $\quad$ Bölgesel Yayılım $\quad$ Ilerlemiş Hastalık

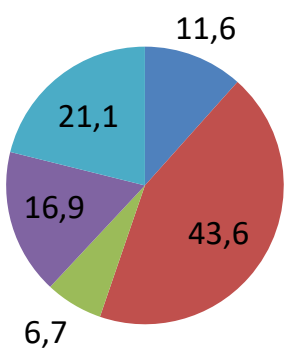

Şekil-2: Hastalık evresine göre hastaların dağııımı.

Tablo-1. Melanom olgularının yaş gruplarına göre dağılımları.

\begin{tabular}{lrr}
\hline Yaş Grubu & Sayı & Yüzde \\
\hline $0-14$ & 13 & 0,8 \\
$15-29$ & 121 & 7,9 \\
$30-44$ & 290 & 19,0 \\
$45-59$ & 491 & 32,1 \\
$60+$ & 615 & 40,2 \\
Toplam & 1530 & 100,0 \\
\hline
\end{tabular}

Tablo-2. Melanomun histopatolojik alt tiplerinin sıklığına göre sıralanması.

\begin{tabular}{lll}
\hline Histolojik alt tip & Sıklık (n) & Sıklık (\%) \\
\hline Yüzeyel yayılan melanom & 179 & 25,5 \\
Lentigo malign melanom & 179 & 25,5 \\
Nodüler melanom & 164 & 23,4 \\
Akral lentijinöz melanom & 150 & 21,4 \\
\hline
\end{tabular}

Hastaların 1475 'inde $(\% 96,4)$ tedavi bilgisi mevcuttu. Tedavi bilgisi mevcut olan hastaların $\% 91,4$ 'üne herhangi bir tedavi uygulanmışken, \%8,6'sına tedavi yapılmadığı görüldü. Cerrahi tedavi hastaların \%80,1'ine yapıldı, \%16,8'ine yapılmadı, \%3,1 hastada yapılıp yapılmadığı bilinmiyordu. Hastaların \%25,6'sına kemoterapi, $\% 8,7$ 'sine radyoterapi, \%1,1'ine immünoterapi uygulandı (Tablo-3). En sık yapılan ilk tedavi tipi $\% 62$ ile cerrahiydi. Hastaların takip süresi 0 ile 313 ay arasında değişmekteydi.
Genel sağ kalım değerlendirmeleri Türkiye Cumhuriyeti kimlik numarası olan 1210 hasta üzerinden yapıldı. Ortalama sağ kalım süresi $147,4 \pm 5,3$ aydı. Yaş artışı ile sağ kalım süresi azalmaktaydı $(p<0,01)$. Yaş gruplarına göre sağ kalım oranları (Şekil-3)'de gösterilmiştir. Erkeklerde ortalama sağ kalım süresi $123,6 \pm 6,4$ ayken, kadınlarda $171,4 \pm 7,8$ aydı. Kadın ve erkek cinsiyet arasındaki sağ kalım süresindeki fark istatiksel olarak anlamlıydı ( $p<0,001)$.

Tablo-3. Hastalara uygulanan tedavi sıklıkları.

\begin{tabular}{ll}
\hline Yapılan tedavi & Sıklık \% \\
\hline Cerrahi & 80,1 \\
Kemoterapi & 25,6 \\
Radyoterapi & 8,7 \\
Immunoterapi & 1,1 \\
\hline
\end{tabular}

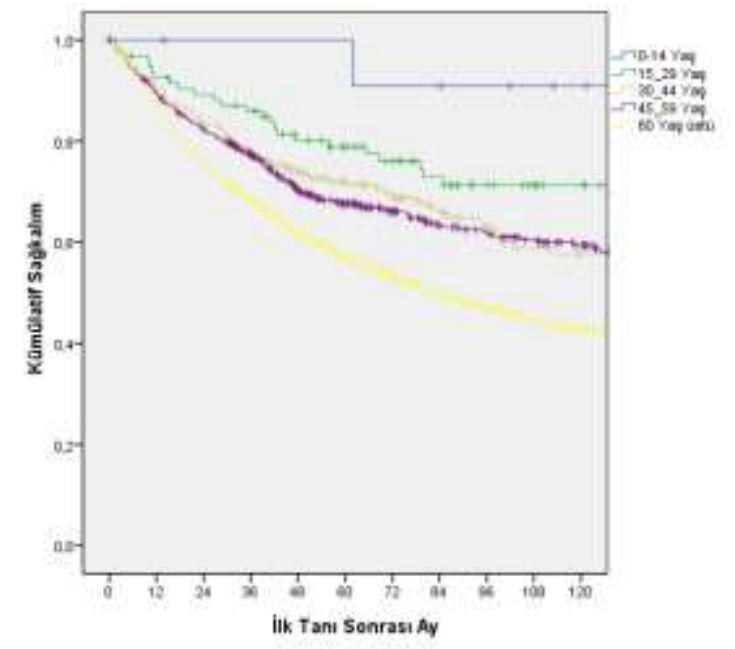

Şekil-3. Yaş gruplarına göre genel sağ kalım oranları. 
Melanomun yerleşim yerine göre en uzun sağ kalım süresi yüzün spesifiye olmamış bölgelerinde yerleşen melanomlara aitti. Yüzün spesifiye olmamış bölgelerine yerleşen melanomlarda saptanan sağ kalım yüksekliği; saçlı deri, alt ekstremite ve kalça ile yerleşim yeri belli olmayan melanomlara göre istatiksel olarak anlamlıydı (p:0,018, p:0,010, p<0,001).

Lentigo malign melanom tanısı alan hastaların \%73,8'i, YYM tanısı alan hastaların \%67,3'ü, ALMM tanısı alan hastaların \%56,5'i, histopatolojik alt tipi belirtilmemiş melanomlu hastaların \%48,8'i ve NM tanısı alan hastaların \%43'ü çalışmanın yapıldığı 2020 yılı itibariyle yaşıyordu. Histopatolojik alt tipi belirtilmiş olan hastalarda 5 yıllık GSK; LMM'da \%79, ALM'da \%72, YYM'da \%69 ve NM'da \%55'ti (Şekil-4).

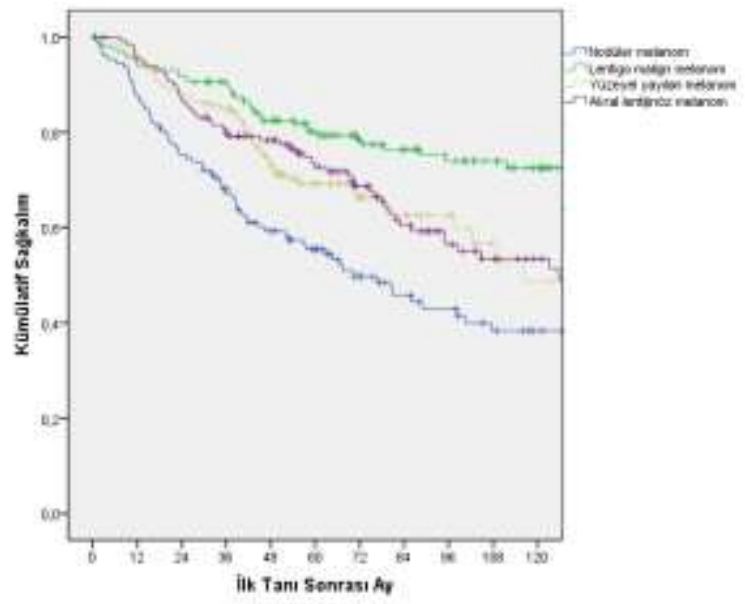

Şekil-4. Melanom olgularının histopatolojik alt tiplerine göre 5 yıllık GSK oranları.

Histopatolojide tümörün in situ olduğu hastaların $\% 89,6$ 'sı hayattayken, in situ olmayan hastaların $\% 52,2$ 'si hayattaydı. İn situ tümörü olan hastaların ortalama sağ kalım süresi $262,9 \pm 12,1$, in situ olmayan hastaların ortalama sağ kalım süresi $138,3 \pm 5,3$ aydı. Tümörün in situ olmasıyla sağ kalım süresinin uzaması istatiksel olarak anlamlıydı $(p<0,001)$.

Lenf bezi tutulumu olmayan hastaların \%75,2'si, olan hastaların ise \%32,5'i hayattaydı. Lenf bezi tutulumu olmayanların ortalama sağ kalım süresi $172,9 \pm 7,4$ ay, lenf bezi tutulumu olanların ise $67,7 \pm 4,6$ aydı. Lenf bezi tutulumu olmamasıyla sağ kalım süresinin uzaması istatiksel olarak anlamlıydı $(p<0,001)$. Metastazı olmayan hastaların $\% 66,1^{\prime} \mathrm{i}$, olan hastaların ise \%9,9'u yaşıyordu. Metastazı olan hastaların ortalama sağ kalım süresi $31 \pm 3,5$ ayken, metastazı olmayan hastalarınki $149,6 \pm 5,1$ aydı. Bu süre arasındaki fark istatiksel olarak anlamlıydı $(p<0,001)$.

Melanom evresinin özet bilgisi olan hastaların içinde lokalize hastalığı olanların \%74,3'ü, lokal yayılımı olanların \%45,5'i, bölgesel yayılımı olanların \%41,2'si, ilerlemiş hastalığı olanların $\% 9,2$ 'si hayattaydı. Lokalize hastalıkta sağ kalım süresi $175,5 \pm 8$, lokal yayılım durumunda $100,2 \pm 12,7$, bölgesel yayılım durumunda $86,8 \pm 6,5$, ilerlemiş hastalıkta $30,6 \pm 3,5$ aydı. İlerlemiş hastalıkta diğer evrelere göre sağ kalım süresinin azalmış olması istatiksel olarak anlamlıydı $(p<0,001)$. Beş yıllık GSK; lokalize hastalıkta $\% 90$, lokal yayılım durumunda $\% 52$, bölgesel yayılımda \%56, ilerlemiş metastatik hastalıkta ise $\% 15^{\prime}$ ti.

Tedavi yapılmayan hastaların ortalama sağ kalım süresi $112,2 \pm 14,3$ ay, tedavi yapılanların $149,9 \pm 5,7$ aydı. Sağ kalım süreleri arasındaki fark istatiksel olarak anlamlıydı (p:0,005). Cerrahi yapılan hastaların ortalama sağ kalım süresi $150,6 \pm 5,5$ ayken, yapılmayanların $105,5 \pm 10,8$ aydı. Sağ kalım süreleri arasındaki fark istatiksel olarak anlamlıydı $(p<0,001)$. Radyoterapi yapılan hastalarda ortalama sağ kalım süresi $75,7 \pm 12,4$ ay, yapılmayan hastalarınki $150,7 \pm 5,3$ aydı. Sağ kalım süreleri arasındaki fark istatiksel olarak anlamlıydı $(p<0,001)$. Ileri evredeki kemoterapi yapılan hastaların ortalama sağ kalım süresi $104,6 \pm 6,8$ ay, yapılmayanlarınki $157,2 \pm 6,3$ aydı. Sağ kalım süreleri arasındaki fark istatiksel olarak anlamlıydı $(p<0,001)$. İleri evredeki immunoterapi yapılan hastaların ortalama sağ kalım süresi $89,4 \pm 11,8$, yapılmayanlarınki $148,2 \pm 5,4$ idi. Sağ kalım süreleri arasındaki fark istatiksel olarak anlamlı değildi ( $p: 0,471)$.

\section{Tartışma}

Son 30 yıldır melanom insidansında artış olmakla birlikte mortalite sabit kalmış ve düşüş göstermiş gözükmektedir. Bu artışın nedeni; tarama programlarının ve sosyal farkındalık çalışmalarının artması, dermatoloji uzman sayısının çoğalması, patologların melanom tanısı koyarken tanı eşiklerinin değişmesine bağlanabilmektedir $(6,7)$. Melanom insidans artışı özellikle Amerika, Avrupa ve beyaz ırkın çoğunlukta olduğu ülkelerde gözükmektedir. Insidansın en yüksek olduğu yer Avustralya'dır (2).

Avrupa'da insidans hızı 100.000'de 10-25'ten daha azken, Amerika'da bu sayı 20-30, 
Avustralya'da ise 50-60'dır (4). Amerika'da melanom insidansı 2002 yılında 1973 yılına göre $\% 270$ artmış olarak saptanmıştır ve hayat boyu 63 kişiden 1'inde melanom gelişeceği tahmin edilmektedir (8). İki bin yirmi yılında Amerika'da 100.350 yeni melanom vakası gelişeceği ve melanoma bağlı 6850 ölüm olacağı tahmin edilmektedir (7). Çin'de yapılan bir çalışmada 2017 yılında melanom insidansı 0,9 olarak görülmüş ve 1990 yılına kıyasla \%110 artış saptanmıştır (9). Global Burden of Disease Cancer Collaboration verilerine göre 2006 ve 2016 yılları arasında melanomda \%39 artış saptanmıştır (10).

Mortalite düşüşündeki artış metastatik hastalıkta kullanılabilen yeni tedavilere bağlanmaktadır. İki bin on bir yılında FDA'nın ipilimumab ve vemurafenibi onaylamasının ardından 2008-2010 yıllarındaki metastatik melanomdaki sağ kalım oranı \%42 iken 2013-2015 yılları arasında \%55'e yükselme izlenmiştir (7).

Türkiye Halk Sağlığı Kurumu'nun kanser istatistik verilerine göre kutanöz melanomun 2014 yılı insidansı erkeklerde 1,8, kadınlarda ise 1,2'dir. İki bin dokuz yılında 353 melanom vakası varken 2014 yılında bu sayı 610 olarak verilmiştir. Bu verilerle kutanöz melanom Türkiye'de en sık görülen en sık 10 kanser içinde bulunmamaktadır. Fakat 0-14 yaş arasındaki kız çocuklarında ve tüm çocuklarda malign epitelyal/melanom 5 . sırada, erkek çocuklarında ise 6. sırada bulunmaktadır (11).

Görüldüğü gibi son yıllarda melanom insidansı artmaktadır ve artışın devam edeceği tahmin edilmektedir. $\mathrm{Bu}$ artış özellikle 60 yaşının üzerindeki erkeklerde daha çoktur (4). Melanom 40 yaş altında kadınlarda, 40 yaş üstünde ise erkeklerde daha sık görülmektedir (12). Çalışmamızda erkek hasta oranı \%53,1'di. Erkek cinsiyet oranı; Amerikan Ulusal Kanser Enstitüsünün 2010-2014 yılları arasındaki 16.807 melanom hastasının sonuçlarının değerlendirildiği çalışmada \%60,2 (13), İsveç Kanser kayıtlarının 2003-2015 yılları arasındaki 19.773 melanom hastasının sonuçlarının değerlendirildiği çalışmada \%49,1 (14) ve Türkiye'de 227 melanom hastasının değerlendirildiği tek merkezli çalışmada \%49,3 olarak saptanmıştır (15).

Melanomun ortalama tanı yaşı 57'dir (8). Ülkemizden Taş F.'nin 2010 yılında 1131 melanomlu hastayı değerlendirdiği çalışmada hastaların ortalama yaşı 52 (12), Baykal ve ark.'nın 227 melanom hastasını değerlendirdiği çalışmada 57,7 (15), Gamsızkan ve ark.nın 1574 hastayı değerlendirdiği çalışmada ise 56,7 olarak saptanmıştır (16). Avustralya'da Wee ve ark.I çalışma gruplarında melanomlu hastalarda ortalama yaşı 58 saptamışlardır (17). Bizim çalışmamızda da literatüre benzer şekilde hastaların ortalama yaşı $54,14 \pm 16,537$ olarak saptanmıştır.

Kutanöz melanom tipleri olan YYM \%41, NM $\% 16$, LMM \%2,7-14 ve ALM \%1-5 oranlarında görülmektedir (4). Avustralya'da 5141 melanom lezyonunun değerlendirildiği bir çalışmada YYM $\% 57,2$, LMM \%20,8, NM \%12,2, ALM \%2,6, desmoplastik melanom \%2,5 oranında izlenmiştir (17). Güney Brezilya'da 1002 melanom lezyonunun değerlendirildiği bir çalışmada YYM $\% 51,6$, NM \%37, LMM \%5,4 ve ALM \%6 oranında saptanmıştır (18). Hindistan'daki bir çalışmada 170 kutanöz melanomun histolojik alt tip oranları; ALM \%59,4, YYM \%32,9, NM \%7,6 idi (19). Türkiye'de Baykal ve ark.nın çalışmasında YYM \%37,1, LMM \%31,4,ALM $\% 19,3$ ve NM \%6,7 (15) oranlarında iken Gamsızkan ve ark.nın çalışmasında YYM \%37,9, NM \%26,2, ALM \%13,2, LMM \%9,1, desmoplastik melanom $\% 0,7$, konjenital nevüsten gelişen melanom \%0,6 oranlarındaydı (16). Mevcut çalışmada YYM \%25,5, LMM \%25,5, NM $\% 23,4, \quad$ ALM \%21,4 oranında görüldü. Melanomun histolojik alt tiplerinin sıklığı coğrafik bölgeler ve ırklara göre değişim göstermektedir.

Melanom yerleşim yeri erkeklerde en sık sırt, kadınlarda da kol ve bacaklardır (8). Wee ve ark.nın çalışmasında melanom yerleşim yerlerinin oranları; baş boyun $\% 28,1$, gövde $\% 28,5$, alt ekstremite $\% 24,6$ ve üst ekstremite $\% 18,8$ olarak belirtilmiştir (17). Güney Brezilya'da yapılan çalışmada gövdede \%47, alt ekstremite \%19,5, üst ekstremite $\% 16,4$, baş ve boyunda yerleşim $\% 17,1$ olarak saptanmış (18). Baykal ve ark.nın çalışmasında baş boyun \%34,7, gövde \%23,6, üst ekstremite $\% 12$, alt ekstremite $\% 28$ oranlarında saptanmıştır (15). Gamsızkan ve ark.nın çalışmasında alt ekstremite $\% 27,3$, başboyun \%25,7, gövde \%23,1 oranlarındadır (16). Mevcut çalışmamızda yerleşim yeri oranları; baş, yüz ve boyun $\% 29,4$, alt ekstremite ve kalça $\% 23$, gövde $\% 21,9$ ve üst ekstremite $\% 12,8$ 'di.

Wee ve ark.nın çalışmasında in situ melanom oranı \%23,4 (17), Baykal ve ark.nın çalışmasında ise $\% 23,1$ (15), Gamsızkan ve ark.nın çalışmasında ise \%8 olarak saptanmıştır (16). 
Bizim çalışmamızda bu oran \%5,9'dur. Bu oranın hastanemizin üçüncü basamak sağlık kuruluşu olması nedeniyle ileri evre hastaların hastanemize sevki nedeniyle olabileceği düşünülmüştür.

Melanom erkek hastalarda kadınlara göre daha mortal seyretmektedir. Erkek hastalarda sağ kalım daha düşük görülmektedir (3). Çalışmamızda da erkek hastalarda GSK süresi kadınlara göre daha düşük saptanmıştır. Yaşın yüksek olması ve ekstremitelere kıyasla gövde, baş ve boyunda yerleşen melanomlarda prognoz daha kötüdür (4). Melanom prognozu hastalık evresi ve dolayısıyla tümör derinliğine göre de değişmektedir (8). Lokalize evredeyken cerrahi ile tedavi edilebilir ve 5 yıllık sağ kalım oranı \%98'dir (2).

Melanom lenfojen ve hematojen metastaz yapabilmektedir. Satellit ve intransit metastazları olanlarda 10 yıllık sağ kalım \%30-50, lenf nodu mikrometastazı olanlarda \%69-75 ve klinik rejyonel lenf nodu metastazında \%40-60'dır. Tedavi edilmeyen uzak metastazda 6-9 aylık ortanca sağ kalım süreleri verilmektedir (4). Uzak metastazda 5 yıllık sağ kalım süreleri \%23'e düşmektedir (2). Bizim hasta grubumuzda 5 yıllık
GSK; lokalize hastalıkta \%90, lokal yayılım durumunda $\% 52$, bölgesel yayılımda $\% 56$, ilerlemiş metastatik hastalıkta ise $\% 15^{\prime}$ ti.

\section{Sonuç}

Bu çalışma, bilgimize göre Türkiye'de en fazla melanom hastası içeren tek merkezli seridir. Çalışmamızda tanı sırasında ileri yaş, erkek cinsiyet, tümörün in situ olmaması, lenf bezi tutulumu ve metastaz varlığı sağ kalımı azaltan faktörlerdir. Beş yıllık GSK nodüler melanomda diğer histopatolojik alt tiplere göre daha kısadır. Beş yıllık GSK; lokalize hastalıkta \%90, lokal yayılım durumunda \%52, bölgesel yayılımda $\% 56$, ilerlemiş metastatik hastalıkta ise \%15'tir. Sağ kalım oranlarından da anlaşılabileceği gibi melanom tanısının erken dönemde konulması elzemdir. Bu nedenle kişilerin melanom ve risk faktörleri konusunda bilinçlendirilmesi, risk faktörlerinin varlığında hastaların özellikle melanositik lezyonların tanı doğruluğunu arttıran dermotoskopi ve takip olanağı sağlayan dijital dermatoskopi yöntemlerinin de olduğu bir merkezde yakın takibi yapılmalıdır.

Çıkar çatışması: Yazarlar çıkar çatışması beyan etmemişlerdir.

\section{Kaynaklar}

1. Garbe C, Bauer J. Melanoma. In: Bolognia JL, Schaffer JV, Cerroni L (eds). Dermatology. $4^{\text {th }}$ ed. China: Elsevier; 2018:1989-2019.

2. Carr S, Smith C, Wernberg J. Epidemiology and Risk Factors of Melanoma. Surg Clin North Am 2020;100(1):1-12.

3. Elçin G, Çakır A. Malign melanom epidemiyolojisi ve risk faktörleri. Demirci U, editör. Cilt Kanserleri. 1. Baskı. Ankara: Türkiye Klinikleri; 2019:5-11.

4. Garbe C, Amaral T, Peris K, et al. European Dermatology Forum (EDF), the European Association of Dermato-Oncology (EADO), and the European Organization for Research and Treatment of Cancer (EORTC). European consensus-based interdisciplinary guideline for melanoma. Part 1: Diagnostics - Update 2019. Eur J Cancer2020;126:141-58.

5. Garbe C, Amaral T, Peris K, et al. European Dermatology Forum (EDF), the European Association of Dermato-Oncology (EADO), and the European Organization for Research and Treatment of Cancer (EORTC). European consensus-based interdisciplinary guideline for melanoma. Part 2: Treatment - Update 2019. Eur J Cancer 2020;126:159-77.

6. Ribero S, Glass D, Bataille V. Geneticepidemiology of melanoma. Eur J Dermatol. 2016;26(4):335-9.

7. Siegel RL, Miller KD, Jemal A. Cancerstatistics, 2020. CA Cancer J Clin. 2020;70(1):7-30.

8. Rastrelli M, Tropea S, Rossi CR, Alaibac M. Melanoma: epidemiology, risk factors, pathogenesis, diagnosis and classification. InVivo. 2014;28(6):1005-11.

9. Wu Y, Wang Y, Wang L, Yin P, Lin Y, Zhou M. Burden of melanoma in China, 1990-2017: Findingsfromthe 2017 global burden of diseasestudy. Int J Cancerdoi: 10.1002/ijc.32764

10. Global Burden of Disease Cancer Collaboration, Fitzmaurice C, Akinyemiju TF, Al Lami FHet al. Global, Regional, and National Cancer Incidence, Mortality, Years of Life Lost, Years Lived With Disability, and Disability-Adjusted Life-Years for 29 Cancer Groups, 1990 to 2016: A Systematic Analysis forthe Global Burden of Disease Study. JAMA Oncol 2018;4(11):1553-68. 
11. Hacıkamiloğlu E, Gültekin M, Boztaş G ve ark. Türkiye Kanser İstatistikleri. Türkiye Halk sağlığı Kurumu. 2017, Ankara.

12. Tas F. Age-specific incidence ratios in malignant melanoma in Turkey: melanoma in older people is increasing. ActaDermVenereol 2011;91(3):353-4.

13. Hieken TJ, Glasgow AE, Enninga EAL, et al. Sex-Based Differences in Melanoma Survival in a Contemporary Patient Cohort. J WomensHealth (Larchmt)doi:10.1089/jwh.2019.7851.

14. Zheng G, Chattopadhyay S, Sundquist K, et al. Association between tumor characteristics and second primary cancers with cutaneous melanoma survival: A nation wide cohort study. Pigment Cell Melanoma Res. doi: $10.1111 / \mathrm{pcmr} .12868$.

15. Baykal C, Atci T, Polat Ekinci A, Buyukbabani N. An update on cutaneous melanoma in Turkey: evaluation of 19-year data in a single tertiary centre and review of the literature. $J$ EurAcadDermatolVenereol. 2017;31(2):236-40.

16. Gamsizkan M, Yilmaz I, Buyukbabani N, et al. A retrospective multicenter evaluation of cutaneous melanomas in Turkey. AsianPac JCancerPrev 2014;15(23):10451-6.

17. Wee E, Wolfe R, Mclean C, Kelly JW, Pan Y. The anatomic distribution of cutaneous melanoma: A detailed study of 5141 lesions. Australas J Dermatoldoi: 10.1111/ajd.13223.

18. Naser N. Cutaneous melanoma: a 30-year-long epidemiological study conducted in a city in southern Brazil, from 1980-2009. An BrasDermatol 2011;86(5):932-41.

19. Panda S, Dash S, Besra K, Samantaray S, Pathy PC, Rout N. Clinicopathological study of malignant melanoma in a regional cancer center. Indian J Cancer 2018;55(3):292-96. 